\title{
Effects of 'extra' ovarian tissue on ovulation number and ovarian steroids in rats
}

\author{
H. Jane Weems Chihal, S. C. Stone and R. D. Peppler \\ Departments of Physiology, Anatomy, and Obstetrics and Gynecology, \\ Louisiana State University Medical Center, New Orleans, Louisiana 70112, U.S.A.
}

Lipschütz (1927) suggested that the number of eggs shed by an animal is not determined by the number of ova present, but by some extra-ovarian factor. When Breward \& Zuckerman (1949) attempted to test this hypothesis, they showed that multiple ovarian grafts in randomly bred female rats caused a decrease in follicular development and the weight of the ovaries in situ. These findings were later attributed to immunological rather than endocrinological factors (Mandl \& Zuckerman, 1951). In the present study, the influence of 'extra' ovarian tissue on the number of eggs ovulated and follicular development was re-investigated using highly inbred Fischer 344 rats. In such strains skin homografts are permanently accepted, verifying the isohistogenicity of the strain (Warren, Lofgreen \& Steinmuller, 1973). Since skin grafts are more difficult to transplant permanently in rats than ovarian grafts (Billingham \& Parkes, 1955), there should be no rejection of ovaries transplanted within a strain.

Female Fischer 344 rats were received at 21 days of age (Microbiological Associates, Walkersville, Maryland) and housed 6/cage under controlled lighting (fluorescent illumination from 05.00 to 17.00 hours) with free access to food and water. Animals were examined daily for vaginal opening. Vaginal smears were taken daily from puberty at $32.0 \pm 0.4$ (S.E.M.) days of age and continued until all rats had been killed.

Rats were assigned to four experimental groups which consisted of 12 animals each. Both ovaries were removed from prepubertal ( 24 days of age) rats using a dorsolateral approach under ether anaesthesia. Each ovary was divided into four equal pieces, and all the pieces from one donor were placed into a subcutaneous (s.c.) flank pouch in an anaesthetized prepubertal (24-day-old) recipient (Group 2). This procedure was repeated using 46-day-old donors (postpubertal) and recipients (Group 4). In addition, prepubertal (24-day-old; Group 1) and postpubertal (46-day-old; Group 3) rats received a sham operation which consisted of ether anaesthesia and preparation of s.c. flank pouches.

Four weeks after grafting, experimental animals and controls were anaesthetized with ether between 14.00 and 17.00 hours at metoestrus (first leucocyte infiltration after a cornified vaginal smear). The abdominal aorta was exposed, and a heparinized blood sample was obtained and centrifuged under refrigeration. The plasma was frozen until assayed. Animals were subsequently killed, and an incision made from the base of the tail to the base of the skull. The skin was dissected free to the anterior axillary line to reveal any grafted tissue.

Grafts and the in-situ ovaries were removed, weighed, fixed in Bouin's fluid, embedded in paraffin wax, serially sectioned at $10 \mu \mathrm{m}$ and stained with haematoxylin and eosin. Follicular size $(>150 \mu \mathrm{m})$ in the in-situ ovaries was determined by measuring two perpendicular diameters at the level of the nucleolus of the oocyte with the identity of the tissue remaining unknown until all tissue had been examined. Ovulation number was determined by dissecting the oviduct away from the ovary, placing it in a cavity cell, flushing it with $0.9 \% \mathrm{NaCl}$, and counting the eggs. Uterine and body weights were also recorded for each animal.

Oestradiol-17 $\beta$ and progesterone were measured in plasma by the radioimmunoassay described by Thorneycroft \& Stone (1972). The steroids were extracted with ether and incubated with specific anti-oestradiol-17 $\beta$ and anti-progesterone antibodies. The separation of the free from the bound radioactive steroid was accomplished using a dextran-coated charcoal incubation. Recovery was monitored by adding known amounts of $\left[2-{ }^{3} \mathrm{H}\right]$ progesterone and $\left[1,2-{ }^{3} \mathrm{H}\right]$ oestradiol- $17 \beta$ to the samples before extraction. 
The results were analysed by Student's $t$ test using $95 \%$ confidence limits.

As shown in Table 1, rats which received two s.c. ovarian grafts after puberty ovulated fewer eggs than sham-operated controls of the same age $(P<0.05)$ and had lower plasma progesterone levels $(P<0 \cdot 05)$. Rats which received two s.c. ovarian grafts before puberty also ovulated fewer eggs than their respective sham-operated controls, but the difference was not significant at the $5 \%$ level. No differences in ovarian weights, uterine weights, cycle length, or plasma oestradiol-17 $\beta$ levels were found for any of the four groups.

Table 1. The effect of 'extra' ovarian tissue on ovulation number and ovarian steroids in Fischer 344 rats (12/group; means \pm S.E.M.)

\begin{tabular}{|c|c|c|c|c|}
\hline & $\begin{array}{c}\text { Group 1 } \\
\text { (controls, } \\
\text { sham surgery) }\end{array}$ & $\begin{array}{l}\text { Group 2 } \\
\text { (two 'extra' } \\
\text { ovaries s.c.) }\end{array}$ & $\begin{array}{c}\text { Group } 3 \\
\text { (controls, } \\
\text { sham surgery) }\end{array}$ & $\begin{array}{c}\text { Group 4 } \\
\text { (two 'extra' } \\
\text { ovaries s.c.) }\end{array}$ \\
\hline Age at time of grafting (days) & 24 & 24 & 46 & 46 \\
\hline Mean no. of ova shed/rat & $8 \cdot 1 \pm 0 \cdot 8$ & $6.2 \pm 0.8$ & $9 \cdot 3 \pm 0.7$ & $5 \cdot 8 \pm 0.5^{*}$ \\
\hline Wt of both in-situ ovaries (mg) & $57 \cdot 7 \pm 2 \cdot 2$ & $53 \cdot 5 \pm 2 \cdot 2$ & $59.5 \pm 1.9$ & $59.8 \pm 1.9$ \\
\hline Uterine wt $(\mathrm{mg})$ & $257 \cdot 5 \pm 14.9$ & $216 \cdot 7 \pm 11 \cdot 0$ & $257 \cdot 3 \pm 8 \cdot 4$ & $264 \cdot 4 \pm 6 \cdot 0$ \\
\hline Oestradiol-17 $\beta(\mathrm{pg} / \mathrm{ml})$ & $60 \cdot 7 \pm 7 \cdot 7$ & $45 \cdot 5 \pm 6 \cdot 5$ & $77.9 \pm 4.6$ & $64 \cdot 1 \pm 6 \cdot 4$ \\
\hline Progesterone $(\mathrm{ng} / \mathrm{ml})$ & $33.9 \pm 1.7$ & $28 \cdot 1 \pm 2 \cdot 2$ & $38 \cdot 1 \pm 2 \cdot 2$ & $30 \cdot 5 \pm 2 \cdot 3$ \\
\hline $\begin{array}{l}\text { Total no. of follicles }>150 \mu \mathrm{m} \text { in } \\
\text { both in-situ ovaries }\end{array}$ & $32 \cdot 0 \pm 4 \cdot 1$ & $41 \cdot 0 \pm 9 \cdot 5$ & $27 \cdot 0 \pm 5 \cdot 0$ & $26 \cdot 7 \pm 6 \cdot 8$ \\
\hline
\end{tabular}

* Significantly different from control, $P<0.05$.

There were no differences in the number of follicles $>150 \mu \mathrm{m}$ in the in-situ ovaries between rats with ovarian grafts and sham-operated control rats. In all instances, the grafted tissue was composed of clusters of healthy follicles surrounded by connective tissue (P1. 1, Figs 1 and 2). More follicles were present in tissue grafted before puberty (Pl. 1, Fig. 3) than in tissue grafted after puberty, but no CL or large follicles (over $150 \mu \mathrm{m}$ ) were found within grafted tissues in either group.

These observations suggest that the grafted tissue had an effect on the ovaries in situ but the reason for the difference in the amount of decrease of ovulation number and progesterone level in the pre- and post-pubertal animals is not known. The mechanism of the decrease in ovulation number after adding 'extra' ovarian tissue is also unknown. The grafts may be metabolizing gonadotrophins so that less gonadotrophin is available to the in-situ ovaries. However, Greenwald (1968) has shown that the levels of gonadotrophins may not control ovulation number. In addition, McLaren (1966) has suggested that the duration of the gonadotrophin stimulus rather than the absolute level, may determine the number of eggs shed. Ber (1971) failed to stimulate the growth of an ovarian autograft on the greater omentum in 16-week-old unilaterally ovariectomized rats by injections of HCG or PMSG to the size attained in castrates with portal ovarian grafts, and concluded that the ovary in situ produces a substance which interferes with the ability of the graft to use gonadotrophins. Such an inhibitory substance could be postulated in the present study, but studies in progress to define the relationship between gonadotrophins and steroids in Fischer 344 rats with ovarian grafts may clarify the mechanism involved.

We thank Dr I. H. Thorneycroft for anti-oestradiol-17ß antibody; Dr D. Tulchinsky for antiprogesterone antibody; J. Canale and S. Hemelt for technical, G. Kerimian for photographic, and E. Schwartz for secretarial assistance.

\section{EXPLANATION OF PLATE 1}

Fig. 1. A cluster of follicles around a connective tissue core in rat ovarian tissue grafted after puberty. $\times 45$. Fig. 2. A follicle in rat ovarian tissue grafted after puberty showing the intact and viable oocyte. $\times 165$.

Fig. 3. Ovarian tissue grafted before puberty showing numerous small follicles. $\times 180$. 

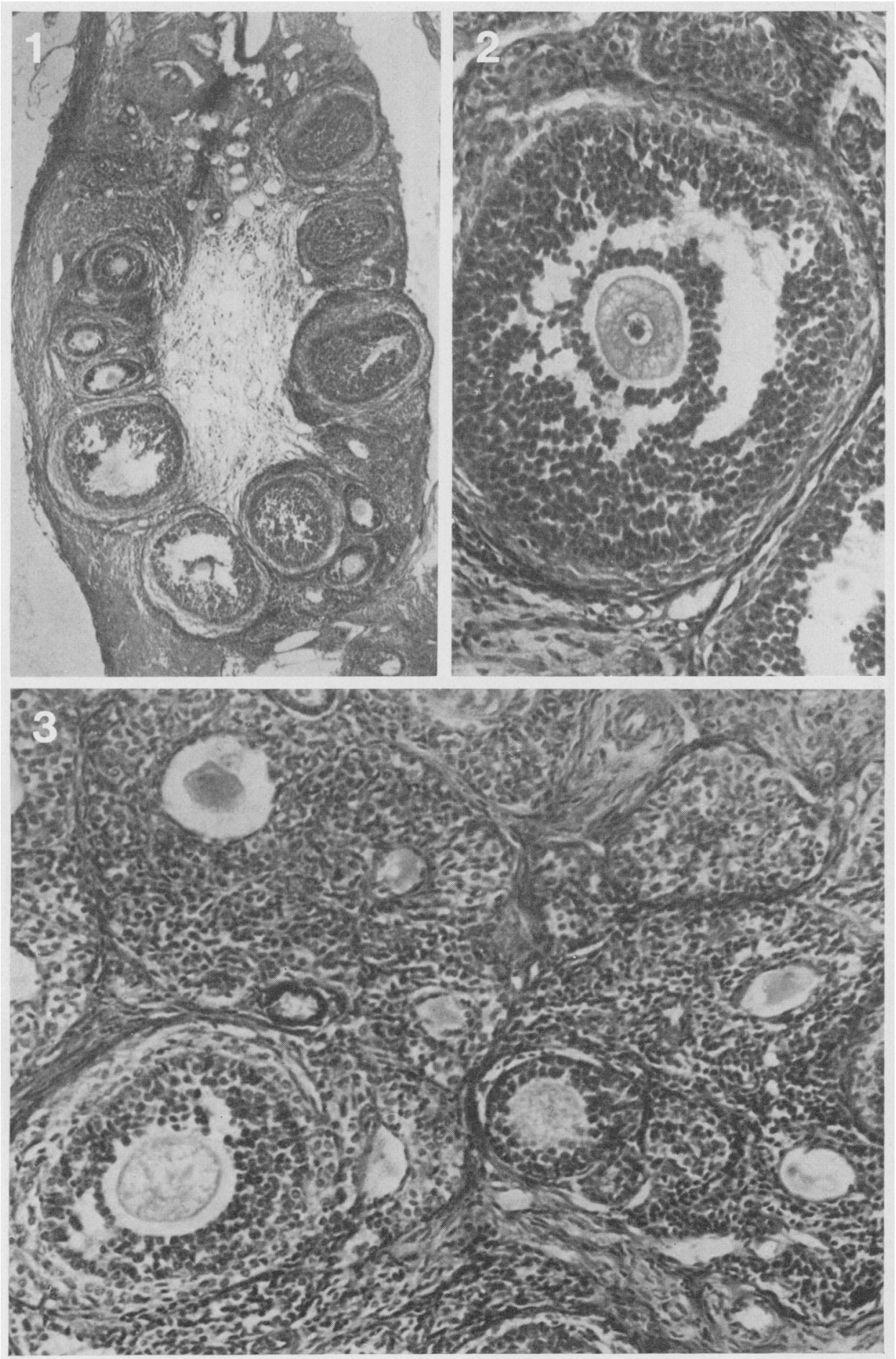


\section{References}

BER, A. (1971) The effect of gonadotrophins and of growth hormone on the development of ovarian autografts on the greater omentum of hemicastrated rats. Acta endocr., Copenh. 66, 99-110.

Billingham, R.E. \& Parkes, A.S. (1955) Studies on the survival of homografts of skin and ovarian tissue in rats. Proc. $R$. Soc. B 143, 550-560.

Breward, M.M. \& ZuCKerman, S. (1949) The reaction of the body to multiple ovarian grafts. $J$. Endocr. 6, 226-234.

Greenwald, G.S. (1968) Influence of one or two ovaries on ovulation and ovarian weight in the hypophysectomized rat. Endocrinology 82, 591-596.

LiPSCHütz, A. (1927) On some fundamental laws of ovarian dynamics. Biol. Rev. 2, 263-280.
MCLAREN, A. (1966) Regulation of ovulation rate after removal of one ovary in mice. Proc. $R$. Soc. B 166, 316-340.

Mandl, A.M. \& Zuckerman, S. (1951) The reaction of the ovaries and adrenal glands in female rats to ovarian and muscle homografts. J. Endocr. 7, 344-348.

ThORNEYCRoFT, I.H. \& Stone, S.C. (1972) Radioimmunoassay of serum progesterone in women receiving oral contraceptive steroids. Contraception 5, 129-146.

WARren, R.P., Lofgreen, J.S. \& Steinmuller, D. (1973) Factors responsible for the differential survival of heart and skin allografts in inbred rats. Transplantation 16, 458-465.

Received 15 September 1975 